\title{
A FORMAÇÃO DO INTÉRPRETE EDUCACIONAL E SUA ATUAÇÃO EM SALA DE AULA
}

\author{
Luiz Cláudio Oliveira ANTONIO ${ }^{1}$ \\ Paola Rodrigues MOTA ${ }^{2}$ \\ Celeste Azulay KELMAN ${ }^{3}$
}

RESUMO: É fundamental contar com a participação do intérprete educacional de Língua de Sinais (LS) na inclusão. Esse artigo aborda a formação e as diferentes funções dos intérpretes em contextos educacionais inclusivos. Basta ser conhecedor da LS? Isso garante ao intérprete o sucesso em sua função? É preciso também agir como mediador entre professor e os alunos surdos, buscando promover a compreensão. Nessa pesquisa foram realizadas entrevistas semiestruturadas com onze intérpretes que atuam na inclusão, buscando conhecer a formação inicial, o tempo de exercício profissional, quais as motivações e quais as funções que desempenha na sala de aula e na escola. Resultados apontam a ausência de planejamento conjunto professor-intérprete e de acesso prévio aos conteúdos apresentados em sala. Verificou-se que quando o intérprete age pedagogicamente, crianças surdas aprendem mais.

PALAVRAS-CHAVE: Formação do intérprete educacional. Educação inclusiva. Língua de sinais.

\section{Introdução}

A escolarização de surdos tem sido alvo frequente de estudos desenvolvidos por pesquisadores das áreas da educação e da linguística, visto que existem duas línguas inseridas neste processo: a Língua Portuguesa, língua majoritária da comunidade ouvinte, que será aqui tratada como segunda língua ou L2 e a Língua de Sinais, legitimada no nosso país como a primeira língua da comunidade surda e que, portanto, será considerada como L1. Mas essa realidade nem sempre foi verdadeira para o cenário educacional brasileiro.

Ao longo da última década, a política de inclusão vem garantindo cada vez mais a presença/acesso de educandos surdos à educação em classes regulares. Para que tal fato ocorra, emergem novos personagens no cenário das classes inclusivas: o professor

\footnotetext{
${ }^{1}$ Tradutor e intérprete de Libras/ Língua Portuguesa Secretaria Municipal de Educação de Nova Iguaçu. Colaborador do Grupo de Estudos e Pesquisas sobre Surdez - GEPeSS. INES - Instituto Nacional de Educação de Surdos. Rio de Janeiro - RJ - Brasil. 22240-003 - lclaudio.libras@ gmail.com

${ }^{2}$ Tradutora e intérprete de Libras/ Língua Portuguesa na Secretaria Municipal da Pessoa com Deficiência - RJ. Colaboradora do Grupo de Estudos e Pesquisas sobre Surdez - GEPeSS. SMPD - Secretaria Municipal da Pessoa com Deficiência. Rio de Janeiro - RJ - Brasil. 20211-110 aloap.olapa@hotmail.com

${ }^{3}$ Coordenadora do Grupo de Estudos e Pesquisas sobre Surdez - GEPeSS. UFRJ - Universidade Federal do Rio de Janeiro - Pós-Graduação em Educação. Rio de Janeiro - RJ - Brasil. 39389-600 celeste@kelman.com.br
} 
bilíngue, o instrutor surdo e o intérprete de Libras. O Decreto 5.626/2005 (BRASIL, 2005), que regulamentou a Lei 10.436/2002 (BRASIL, 2002), determinou que as pessoas surdas tivessem acesso à comunicação, à informação e à educação desde a educação infantil até a superior. Em decorrência, o professor bilíngue, o instrutor surdo e o intérprete passaram a estar presentes no cenário educacional para os estudantes surdos brasileiros, embora se tenha clareza que em muitos ambientes educacionais eles ainda não estejam presentes. Em seu Capítulo IV, sobre o Uso e a Difusão da Libras e da língua portuguesa para o acesso das pessoas surdas à educação, o Decreto dispunha de temáticas tais como a formação docente, a garantia da Língua na escolarização dos surdos e sobre o tradutor e intérprete de Libras - Língua Portuguesa. É dentro deste último tópico que este trabalho se insere.

O profissional tradutor/intérprete de Língua de Sinais (TILS) não é um personagem recente na história da comunidade surda. Sua atuação iniciou-se "[...] a partir de atividades voluntárias que foram sendo valorizadas enquanto atividade laboral na medida em que os surdos foram conquistando o seu exercício de cidadania." (QUADROS, 2004, p.13).

Entretanto, o cenário educacional contemporâneo brasileiro, inclusivo, tem sido alvo frequente de discussões quando se debate o processo da educação de surdos. Um item em pauta, quando o tema é tratado, refere-se à sua formação para o exercício da tradução/interpretação em ambientes escolares e de convívio social.

Para assegurar uma participação adequada dos surdos nesses diversos espaços sociais, o TILS precisa ter uma formação que implique reflexões sobre as especificidades surdas, que envolvem a língua e a cultura surdas; os conhecimentos da área onde pretende atuar e uma atitude ética, responsável e compromissada. Uma interpretação deficiente ou insuficiente pode causar prejuízos sérios aos surdos. Muitas vezes, é necessário também se estabelecer parceria com outros intérpretes, principalmente em momentos que envolvem tempo prolongado de atuação, como é o caso de alguns eventos (FERNANDES apud DORZIAT; ARAÚJO, 2012, p.394).

Convém ressaltar que no desempenho da função em escolas é pouco provável que haja dois intérpretes se revezando. Normalmente o que se vê no ensino fundamental, principalmente no primeiro segmento, é um único intérprete designado para cada sala de aula. Entretanto, interpretar para turmas com nível de escolarização mais elevado deveria implicar em uma divisão não mais por turma, mas por área de conhecimento. 
O artigo 22 do Decreto 5.626/2005 (BRASIL, 2005) trata sobre o tradutor e intérprete de Libras - Língua Portuguesa. Justifica-se a presença deste quando é abordado o tema da garantia do direito à educação de pessoas surdas ou com deficiência auditiva em uma política de inclusão em escolas e classes bilíngues, abertas a alunos surdos e ouvintes. Logo, a presença do tradutor e intérprete de Libras - Língua Portuguesa - TILS no cenário de escolarização de surdos torna-se relevante.

Segundo Kelman (2008), o intérprete educacional atua como parte da equipe educacional da escola, atendendo a várias crianças, mas existem casos em que esse profissional é contratado pelos pais da própria criança ou até mesmo pela própria escola, dedicando-se exclusivamente a um aluno. Em alguns desses casos o contato com a equipe docente não ocorre ou ocorre de maneira inadequada, distante.

Nesse contexto, a formação do TILS no cenário educativo assume papel mais específico, caracterizando-o como um personagem ativo na educação, embora não tenha ainda suas funções claramente definidas. Para que estudantes surdos possam ter o acesso, a permanência e um bom desempenho no processo ensino-aprendizagem nas salas de aula inclusivas, é preciso que se defina melhor as funções do profissional intérprete. Sua mediação corroborará no desenvolvimento da aprendizagem dos alunos surdos (ALBRES; SANTIAGO, 2012). O Decreto não especifica as diferentes funções que o TILS possa vir a exercer. No contexto desse artigo, e por exercer a sua função profissional dentro da escola, passaremos a denominá-lo de intérprete educacional.

Entendemos que o intérprete educacional atua em um contexto intrinsecamente diferenciado, necessitando de uma formação mais específica. A simples presença deste em sala de aula não garante, do ponto de vista metodológico e socioeducacional, a adequação necessária para o sucesso escolar dos estudantes surdos:

[...] a presença de um Tils não garante que questões metodológicas sejam consideradas e também não existe garantia de que o espaço socioeducacional em um sentido mais geral seja adequado, pois a criança surda poderá permanecer às margens da vida escolar [...]. (LACERDA, 2013, p.34)

Lacerda (2013) endossa a importância deste profissional na mediação da comunicação entre surdos e ouvintes, corroborando para o desenvolvimento do indivíduo surdo. A Lei $\mathrm{n}^{\circ}$ 12.319, de $1^{\circ}$ de setembro de 2010 (BRASIL, 2010), reconhece a profissão de tradutor e intérprete de Libras- Língua Portuguesa, fortalecendo as políticas preconizadas na Lei 10.436/02 (BRASIL, 2002) e no Decreto 
5.626/2005 (BRASIL, 2005). Para além de discussões legislativas, o enfoque há de ser posto no campo formativo desse profissional, uma vez que, antes das leis supracitadas, os intérpretes atuavam de forma exclusivamente empírica.

O artigo 17 do Decreto 5.626/05 discorre sobre a formação do intérprete, mencionando que ela deva ocorrer por meio de cursos superiores de tradução e interpretação, habilitando-os em ambas as línguas (Língua de Sinais e Língua Portuguesa) (BRASIL, 2005). Surge, então, o curso de graduação/bacharelado em Letras/Libras na modalidade Ensino à Distância.

A partir de 2008, teve início o primeiro curso de graduação/bacharelado para tradutores/intérpretes Librasportuguês oferecido por universidades públicas, na modalidade Ensino à Distância (EAD) com polos espalhados por todo o país, coordenados pela Secretaria de Educação Especial do Ministério da Educação e pela Universidade Federal de Santa Catarina (UFSC). (LACERDA, 2013, p.24).

Concomitantemente houve a possibilidade de outra formação como "medida paliativa", durante os primeiros dez anos do ato de publicação do Decreto. Essa formação seria em nível médio, através de extensão universitária, traduzindo-se por um curso de educação profissional e de formação continuada, promovidos por instituições de ensino superior e credenciados pelas Secretarias Estaduais de Educação. Entretanto não se esgotam aqui os questionamentos quanto à formação de tradutores e intérpretes de Libras/Língua Portuguesa. Um novo assunto a ser discutido emerge no campo: o intérprete educacional e sua formação - fato pouco discutido no Brasil.

A simples transposição linguística, para Lacerda (2013), não é suficiente para sanar questões metodológicas e socioeducacionais dos alunos surdos. O intérprete nesse contexto necessita de uma formação que o "capacite" para a atuação educacional, fornecendo subsídios para mediar o processo de construção de conhecimentos desses discentes. Wolbers et al. (2012) realizaram um estudo que examinou o quanto da interpretação seguia ao pé da letra o que o professor dizia (interpretação paralela) e com que frequência o intérprete fazia uma interpretação divergente, acrescentando ou dispensando elementos, de forma a facilitar a compreensão do aluno surdo. Concluíram que em 33,2\% do tempo a intérprete educacional atuava de forma paralela e nos $66,8 \%$ restantes a interpretação era divergente, sempre com a preocupação de ampliar o grau de compreensão da língua oral e do conteúdo acadêmico apresentado. Assim, havia a 
primazia do interesse em que o aluno surdo realmente aprendesse e os intérpretes não ficavam restritos a uma simples tradução do que o professor falava.

Para Bueno (1999), o ensino de qualidade para alunos com necessidades especiais exige pelo menos dois tipos de formação profissional docente: professores generalistas e especialistas, com conhecimentos mínimos específicos nas diferentes áreas da educação especial. Silva, Kelman e Salles (2010) afirmam que, em relação ao aluno surdo, as dificuldades vão além desses aspectos, tendo em vista que são poucas as possibilidades de formação específica e sistemática na área.

Esta é uma realidade ainda em construção no campo das pesquisas e da formação, haja vista que a temática formativa de tradutores e intérpretes de Libras/Língua Portuguesa em ambientes não específicos também é recente. São poucos os trabalhos que têm como objeto de estudo a formação e a atuação do intérprete de língua de sinais (KELMAN, 2005; 2008; KELMAN; TUXI, 2010; KOTAKI; LACERDA, 2013; LACERDA, 2010; LACERDA; LODI, 2009) dentre outros. Foi essa polêmica que motivou a construção do presente estudo, com o intuito de contribuir para o conhecimento de uma área que ainda necessita de aprofundamento e definições.

\section{Tradutor-intérprete de língua de sinais - TILS}

Ao longo de décadas o profissional tradutor-intérprete de língua de sinais - TILS veio se constituindo empiricamente, mediante o contato com a comunidade surda e seu desempenho informal nas demandas sociais dos próprios surdos (ALBRES, 2011; LACERDA, 2010). Estes, os surdos, por serem os agentes “detentores” da Língua de Sinais, legitimavam ou não os ouvintes como TILS, em função da demanda social do momento.

Por meio da legalização da Língua Brasileira de Sinais - Libras, ocorreram inúmeros avanços significativos para o campo linguístico e social da comunidade surda, bem como fatores inerentes à sua escolarização. Após a Lei 10.436/02 (BRASIL, 2002), legitimadora linguística da Libras, outros avanços foram galgados: o direito de os surdos se comunicarem livremente através da sua língua, o direito à educação, ao ensino e ao exercício de sua cidadania em Libras, entre tantas outras situações.

Atrelada a essa conquista, por meio do Decreto 5.626/05 (BRASIL, 2005), implementou-se a obrigatoriedade da presença do TILS nos ambientes de escolarização de surdos e a implementação da Libras na formação docente. O Decreto legalizou a instituição do Prolibras, exame de Proficiência em Língua de Sinais, a nível nacional, 
com o objetivo de certificar Instrutores, Professores e Tradutores-Intérpretes de Língua de Sinais. O exame reconhecia assim a importância de avaliar a fluência dos que atuam nessa área, com dois níveis distintos de proficiência: superior e médio. Estes ganhos foram significativos para a comunidade surda brasileira e resultaram na legalização da profissão do tradutor-intérprete de língua de sinais cinco anos depois - Lei $\mathrm{n}^{\circ}$ 12.319/10 (BRASIL, 2010). Hoje o exame tende a ser substituído por formação específica de intérprete, em curso de graduação no ensino superior.

Paralelamente, emerge a discussão referente a formação do TILS, um profissional não mais desconhecido e/ou ilegítimo. As discussões aqui levantadas se aprofundam pensando que, para além da formação do tradutor-intérprete de língua de sinais, há que se considerar a formação do tradutor-intérprete de língua de sinais atuando na educação, doravante passando a ser chamado de intérprete educacional (IE), visto que este atua em um campo específico e que “[...] perpassa as questões de competência na língua portuguesa e na língua de sinais e de suas competências na área educacional para atuar junto a alunos surdos incluídos no ensino regular." (ALBRES, 2011, p. 2154).

Na década de 90, a Federação Nacional de Educação e Integração dos Surdos (FENEIS) propôs algumas tentativas de formação mais específica para TILS, justificadas pela constatação da heterogeneidade de desempenho dos intérpretes. Com isso, propõe cursos de curta duração para formação. O intérprete, segundo a FENEIS, deveria ser imparcial, não deixando que suas opções pessoais, religiosas ou de amizades interferissem em seu trabalho; contribuindo para o fortalecimento e reconhecimento da profissão, realizando cursos de capacitação e oficinas de aprimoramento, além de encontros para discussão de temas relacionados à área.

Pensando em um viés de perfil profissional na educação, é perceptível que a demanda formativa se torna elementar e indissociável do sucesso escolar na aprendizagem de educandos surdos. Para tal, entende-se que simplesmente a presença destes TILS no ambiente escolar não é suficiente para que o processo ocorra de forma positiva academicamente, tendo em vista que o papel do IE transcende o simples ato de verter códigos linguísticos, sendo um ato complexo de compreensão de sentidos. Como diz Lacerda (2010, p.147):

O intérprete não é alguém passivo, um instrumento que verte de uma língua a outra, automaticamente, palavras. É um interlocutor ativo, que, buscando compreender os sentidos 
pretendidos pelo locutor, justamente por ter uma escuta plural, elege aqueles mais pertinentes e os verte para a língua-alvo. Trabalha ativamente na compreensão de sentidos em uma língua e na produção destes mesmos sentidos na outra. Justamente por isso, os conhecimentos do intérprete precisam ser amplos para que possa buscar os sentidos pretendidos por aquele que enuncia e os modos de dizer este mesmo sentido na língua que tem por tarefa alcançar.

Logo, refletirmos sobre as propostas de formação acadêmica específicas para estes profissionais torna-se primordial para o processo de escolarização dos educandos surdos. Também contribui para o fortalecimento profissional da categoria, proporcionando-lhes garantia de reconhecimento e qualificação profissional. O trabalho aqui apresentado voltou-se para o campo, buscando tentar responder a alguns questionamentos nesta área do conhecimento, a fim de cumprir o papel da comunidade acadêmica em fornecer, à sociedade, meios que facilitem o acesso à democratização, cidadania e desenvolvimento do aluno surdo, entendendo que não basta garantir a inclusão e a permanência. Faz-se necessário e premente buscar meios mais eficazes para promover o conhecimento do aluno surdo. Este é o maior desafio do momento: promover a escolarização com resultados satisfatórios. Certamente o IE tem um papel relevante para se alcançar esse objetivo.

É inegável a predominante heterogenia linguística existente no ambiente escolar, inclusivo ou não, já que, na maioria dos casos, os alunos surdos são filhos de pais ouvintes. Consequentemente, ao ingressarem na escola, possuem pouco ou nenhum contato com a Língua de Sinais e, portanto, possuem pouca competência linguística, levando o IE a desdobrar-se para atendê-los da melhor forma possível, necessitando assumir também um papel como educador para que o surdo compreenda o conteúdo do que estava sendo ensinado (CÓRDOVA, 2009; KELMAN; TUXI, 2010).

O aluno surdo chega, portanto, à escola, seja na educação infantil ou no ensino fundamental, sabendo pouco ou nada de língua de sinais. E ainda, como níveis de escolarização mais elevados são recentes na vida acadêmica dos estudantes surdos, muitos significados das diferentes disciplinas ainda carecem de um sinal apropriado ou mesmo de uma nacionalização do sinal correspondente a determinado conceito científico, nas mais diferentes disciplinas escolares, como Química, Física, Biologia, Artes ou Literatura, para citar apenas algumas. 


\section{Objetivo}

Este trabalho buscou investigar a atuação do intérprete de Língua de Sinais em contextos educacionais inclusivos, de forma a conhecer a formação que os profissionais que atuam em contextos educacionais têm e quais qualidades deveriam apresentar para atuar em ambientes educacionais, de forma a fundamentar uma melhor aprendizagem dos estudantes surdos.

\section{Método}

Para se conhecer um recorte da realidade atual dos intérpretes que atuam em escolas, optou-se por uma pesquisa qualitativa. A realidade estudada passa a ser considerada como um fenômeno cultural, histórico e dinâmico, experienciado e descrito pelo pesquisador a partir de seu ato de perguntar e ouvir as narrativas. Nesse sentido, os resultados aqui expostos têm uma dimensão histórica da época em que estão sendo analisados, adotando-se uma perspectiva histórico-cultural. Freitas (2002) assinala que os sujeitos pesquisados são concretos, históricos e marcados por uma cultura como criadores de ideias e consciência, produzindo e reproduzindo uma realidade social ao mesmo tempo em que são produzidos e reproduzidos por essa mesma realidade. Nesse sentido, essa pesquisa retrata um momento e um local específico na linha do tempo referente à profissionalização e formação do intérprete educacional.

As entrevistas tiveram um roteiro flexível, pouco estruturado, de forma que pudessem revelar melhor a subjetividade dos participantes, as tensões vividas por cada um dos entrevistados em diferentes projetos inclusivos bilíngues, já que a contratação de TILS envolve mais do que facilitar a circulação de duas línguas (SALES, 2014). Optou-se por esse instrumento metodológico porque ele permite melhor produção de conhecimentos, já que o entrevistador pode manter o foco na qualidade da interação (MADUREIRA; BRANCO, 2001; MANZINI, 2003). Definidas as concepções epistemológicas e metodológicas desse trabalho, as entrevistas semiestruturadas foram realizadas com onze profissionais que atuam em espaços educacionais inclusivos e que apresentam quatro perfis diferentes, conforme classificação abaixo.

Dentre outras informações, investigou-se sobre sua formação, tempo de atuação no exercício profissional, razões da escolha e quais as suas funções dentro da sala de aula e em outros espaços na escola, objetivando trazer para a pauta de discussão a formação mais adequada para o exercício tradutório-interpretativo em ambiente 
educacional, tendo em vista as peculiaridades presentes nesse espaço formativo para os educandos surdos.

O Quadro 1, a seguir, dispõe as características dos TILS entrevistados, partindo dos seguintes perfis: Perfil 1- Profissional sem formação alguma; Perfil 2- Profissional com formação de tradutor/intérprete de Libras; Perfil 3- Profissional com formação de professor e Perfil 4- Profissional com formação de professor e formação de tradutor/intérprete de Libras.

\section{Quadro 1 - Características dos TILS entrevistados}

\begin{tabular}{|c|c|c|c|c|c|}
\hline PERFIL & $\begin{array}{c}\text { IDENTIFI- } \\
\text { CAÇÃ O }\end{array}$ & IDADE & $\begin{array}{l}\text { TEMPO } \\
\text { DE TIL }\end{array}$ & $\begin{array}{c}\text { TEMPO } \\
\text { COMO IE }\end{array}$ & $\begin{array}{c}\text { ETAPA DA } \\
\text { ESCOLARIZAÇÃO } \\
\text { EM QUE ATUA } \\
\end{array}$ \\
\hline Perfil 1 & $\begin{array}{l}\text { TILS } 1 \\
\text { TILS } 2 \\
\text { TILS } 3\end{array}$ & $\begin{array}{l}28 \text { anos } \\
26 \text { anos } \\
36 \text { anos }\end{array}$ & $\begin{array}{l}10 \text { anos } \\
6 \text { anos } \\
22 \text { anos }\end{array}$ & $\begin{array}{l}6 \text { anos } \\
6 \text { anos } \\
8 \text { anos }\end{array}$ & $\begin{array}{l}8^{\circ} \text { ano } \\
6^{\circ}, 7^{\circ}, 9^{\circ} \text { Ano } \\
\text { Não Informado }\end{array}$ \\
\hline Perfil 2 & $\begin{array}{l}\text { TILS } 4 \\
\text { TILS } 5\end{array}$ & $\begin{array}{c}27 \text { anos } \\
\text { Não } \\
\text { Informado }\end{array}$ & $\begin{array}{l}9 \text { anos } \\
6 \text { anos }\end{array}$ & $\begin{array}{l}4 \text { anos } \\
2 \text { anos }\end{array}$ & $\begin{array}{l}7^{\circ} \text { ano } \\
\text { EJA }\end{array}$ \\
\hline Perfil 3 & $\begin{array}{l}\text { TILS } 6 \\
\text { TILS } 7 \\
\text { TILS } 8\end{array}$ & $\begin{array}{l}34 \text { anos } \\
29 \text { anos } \\
18 \text { anos }\end{array}$ & $\begin{array}{l}10 \text { anos } \\
8 \text { anos } \\
6 \text { meses }\end{array}$ & $\begin{array}{l}6 \text { anos } \\
5 \text { anos } \\
6 \text { meses }\end{array}$ & $\begin{array}{c}1^{\circ} \text { ano - Ensino Médio } \\
7^{\circ} \text { ano } \\
4^{\circ} \text { E } 9^{\circ} \text { Ano }\end{array}$ \\
\hline Perfil 4 & $\begin{array}{l}\text { TILS } 9 \\
\text { TILS10 } \\
\text { TILS } 11\end{array}$ & $\begin{array}{c}32 \text { anos } \\
25 \text { anos } \\
\text { Não } \\
\text { Informado }\end{array}$ & $\begin{array}{l}14 \text { anos } \\
13 \text { anos } \\
10 \text { anos }\end{array}$ & $\begin{array}{c}14 \text { anos } \\
3 \text { anos } \\
\text { Não } \\
\text { Informado }\end{array}$ & $\begin{array}{c}\text { Ens. Fund. II e } \\
\text { Graduação } \\
\text { Graduação } \\
\text { Ens. Fundamental II }\end{array}$ \\
\hline
\end{tabular}

Fonte: Elaboração própria.

Partimos da hipótese que ainda há falta de planejamento conjunto entre o professor regente e o TILS que atua em sua turma, bem como falta acesso prévio aos conteúdos apresentados. Isso nos levou a pesquisar e discutir como, através dos resultados obtidos, poderemos contribuir para o melhor resultado escolar dos educandos surdos, no que tange à atuação do tradutor/intérprete de Língua de Sinais. 


\section{Resultados}

As falas foram sistematizadas de acordo com o perfil em que cada entrevistado se encaixava, agrupando-se as respostas de acordo com os quatro perfis supracitados. Posteriormente os dados foram confrontados com a hipótese inicial mencionada.

\section{Perfil 1: Tradutor/ intérprete sem formação}

Para os três TILS que se enquadram neste perfil, há predominantemente uma concepção de IE como um mero tradutor da língua fonte para a língua alvo, embora emerja, em alguns momentos, uma perspectiva pedagógica, ainda que microscópica.

A gente nunca vai tirar o caso, o que o professor já faz, que é dar essa responsabilidade ao intérprete. Se a gente sempre for agir como um instrutor, como um professor-intérprete, acho que a gente nunca vai tirar esse conceito de que o aluno é do intérprete e não do professor. Então seria uma questão de segurança e uma questão de profissionalismo mesmo. O intérprete atuar como um intérprete. (TILS 1).

[...] Explicava, mas eu tenho a consciência que não é o correto. $\mathrm{O}$ ideal é que o próprio professor explique. (TILS 2).

Em sala de aula tradução, ora em português ora língua de sinais né, na mediação quando há trabalhos em grupos também no ensino superior e também avaliação, na hora das avaliações que o professor faz, inclusive até algumas filmadas em língua de sinais com os alunos. (TILS 3).

Entretanto, o discurso dos intérpretes do Perfil 1 é carregado de ambiguidades que culminam numa busca por posicionamento político, possivelmente em função da falta de formação específica que os caracteriza. Seus discursos, em muitos momentos, evidenciam que os TILS aparentam buscar uma identidade ainda em construção, ou seja, mostram-se "perdidos", ambivalentes em sua posição de quais funções devem desempenhar.

[...] IE a gente perde um pouco essa coisa do simplesmente estar ali como intérprete, a gente não deixa de ter esse feedback momentâneo, instantâneo quando a gente percebe a dúvida do aluno; então não tem como ignorar isso. Então naquele momento ali é [...] A gente acaba fazendo... em parte, a gente acaba fazendo um papel de um professor, um explicador naquele momento porque é uma dúvida direta, é um questionamento simples, um questionamento básico [...] (TILS 1).

No ideal o intérprete tem que só interpretar, mas tem dado momento que eu percebia, eu sempre tentava deixar claro isso se você está com dúvida vá ao professor perguntar ao professor [...] Então às vezes, eu dava um exemplo um pouco diferente, se eu via que aquele ele não "pescava" eu tentava fazer outro diferente. E já teve um ano que eu 
tive que [...] Explicar mesmo! [...] Então eu por mais [...] Assim [...] Como posso dizer? Por um pouco de pena [...] (TILS 2).

No ensino médio, no ensino fundamental, às vezes tinha que servir de professor, instrutor do aluno surdo [...] (TILS 3).

\title{
Perfil 2: Tradutor/ intérprete com formação de intérprete de língua de sinais
}

Os intérpretes com esse perfil, por sua vez, percebem seu papel no ambiente escolar como atores em um viés menos pedagógico, atribuindo ao professor a responsabilidade que lhe é devida.

\begin{abstract}
Porque o intérprete não é o responsável pelo aluno, ele é apenas um ponto de comunicação para que flua ali a aula. [...] Traduzir, porque as pessoas confundem tradução com aula particular. (TILS 4).

[...] eu acredito que a responsabilidade do conhecimento não é do intérprete, é do professor, e o intérprete está ali pra, entre aspas, mediar e aí ele vai além disso, o IE vai além da mediação, mas no processo de educar, ele não vai estar educando aquele aluno. [...] (TIL5).
\end{abstract}

Nos relatos acima é perceptível que os TILS não se veem com a responsabilidade tal qual a de um professor, embora o TIL5 compreenda que seu papel vai além da mera transposição de códigos linguísticos. Para ele, o intérprete atuante no ambiente educacional assume um papel de mediador que participa no processo pedagógico, contribuindo para a subjetividade e construção da identidade dos estudantes surdos.

Ambos (TILS 4 e TILS 5) compartilham do pensamento de que seria ideal haver uma formação que abrangesse tanto as peculiaridades existentes no ambiente escolar, quanto as técnicas de tradução. Apesar de possuírem a mesma formação, a visão de IE é bastante divergente, uma vez que para o TILS 4 a sua atuação é restrita ao ato interpretativo.

\section{Perfil 3: Tradutor/ intérprete com formação de professor}

De acordo com os dados coletados nas entrevistas e possivelmente em função dos professores regentes dessas classes não se sentirem responsáveis pelos alunos surdos, os intérpretes educacionais deste perfil acabam por assumir a responsabilidade de professor desses estudantes.

Em muitos momentos, também meio como professora... Até por conta da sala de aula ser superlotada, o professor nunca liga para o aluno surdo... E por conta disso o aluno surdo nunca vai até o professor e 
pede uma explicação ao professor... Ele acaba pedindo ao intérprete. (TILS 6).

Isso, exato! Porque o professor em si, dentro de sala de aula, ele não era tão presente, então eu tinha que vestir a camisa como intérprete e como professor ao mesmo tempo, porque o ensino é muito defasado, ou seja, tem a parte de discriminação, o professor às vezes não dava atenção para o surdo eu teria que vestir a camisa como professor. Isso aí me incomodava muito. Então eu buscava informações que o professor do ensino regular não tem. Eu buscava informações de fora para passar esse conteúdo pro aluno. (TILS 7).

[...] mas eu já tive casos em que os professores passavam muito longe do aluno surdo, não sabiam nem o nome. Na metade do ano, uma professora chegou pra mim e perguntou se a aluna era surda porque ela achava que a aluna só tinha déficit de atenção [...] (TILS 8).

Embora não haja ênfase em suas falas, os entrevistados citam, em algum momento, a "importância" de possuir uma formação mais específica na área da tradução. Em contrapartida, percebe-se que estes profissionais, por não terem a formação específica de intérprete e sim de professores, assumem um papel docente.

Com certeza. Eu ainda não tenho formação, no caso é, eu estou querendo, ainda, breve, fazer o curso de extensão como tradutor intérprete de Libras e também eu acho importante não só por uma questão de título, mas também por uma questão de conhecimento e por, pelo embasamento que isso vai ter uma segurança pra você trabalhar em sala de aula. Porque às vezes a gente, nós vamos trabalhar cheios de ponto de interrogação e a gente não sabe se o que a gente tá fazendo é certo ou errado, e tendo teorias que nos embasem pra trabalhar a gente vai: não, eu escolhi trabalhar dessa maneira, essa é a minha linha, e eu vou fazer assim. (TILS 8).

\section{Perfil 4: Tradutor/ intérprete com formação de professor e de intérprete de língua de sinais}

Não eu nunca vou conseguir dar conta dos conteúdos, sendo intérprete. Até mesmo que eu pudesse dar conta, não é minha função. Mesmo que eu pudesse dar conta dos conteúdos por conta da minha formação, eu não planejei a aula, não tenho aquele olhar pedagógico que um professor tem ao entrar numa sala, o nosso olhar é diferenciado, embora tenha um olhar pedagógico, mas é um olhar pedagógico voltado à língua, a de mediação mesmo, que se tenha um toque de ensino, mas não é o mesmo, uma visão que um professor vai ter. (TILS 10).

Mediante o relato acima descrito, percebe-se que a formação, envolvendo tanto a parte pedagógica quanto a formação técnica de interpretação, traz um olhar diferenciado do profissional sobre a sua prática. Está claro que o TILS 10 compreende que ele não atua como professor, mas que seu papel está indissociável dessa vertente. 
Além disso, ao ser questionado em relação ao papel do IE, salienta, que este profissional possui inúmeras vertentes de atuação de acordo com o nível de escolarização em que está atuando. Dentre essas possibilidades, associa que deveria constar do bom trabalho do intérprete o de atuar no planejamento com o professor da classe nas séries iniciais, distanciando-se gradativamente na medida em que o aluno ascende nos níveis de escolarização:

Em geral pensa-se da seguinte forma: que o intérprete atuaria como se fosse uma dupla regência nos anos iniciais, do $1^{\circ}$ ao $5^{\circ}$ ano, mas pra isso ele tem que ter uma formação de professor também, então não seria intérprete, seria um professor bilíngue, de co-regente, e depois disso ele atuaria tendo os conhecimentos pedagógicos, aplicando-os, mas, ao levar o nível de formação deste, dos surdos, o nível de distanciamento do intérprete também ocorre até que ele chegue numa universidade com um distanciamento a ponto que ele vai se tornar um meio intermediador linguístico apenas.

[...] Então a função do intérprete até hoje não se sabe. O que se sabe é que tem que se ter o conhecimento das práticas pedagógicas, e que ele está ali para fazer uma intermediação juntamente com o professor, nunca um trabalho que seja separado [...] (TILS 10).

O TILS 11 ratifica esse distanciamento existente nos níveis elevados de formação, em razão de atuar no Ensino Superior:

Bom, no momento que eu estou atuando em sala de aula não, mas a gente sabe que tem colégios que ainda confundem bastante, que misturam essa atuação né, não sabem separar que ali eles estão só como intérprete e não como professores, mas eu procuro inclusive pela questão ética, eu sei que ali eu estou só como mediadora, eu não sou professora dos alunos surdos. Apesar de que na educação inclusiva, de uma maneira geral, a gente sabe que tem essa confusão por parte do professor que responsabiliza o intérprete como se o intérprete fosse responsável por aquele aluno e às vezes acontece, mas no ensino superior essa separação tem que ser ma-a-ior ainda do que deveria ser também nos outros segmentos [...] Eu estou ali como intérprete, eu não dou resposta pro aluno, eu não interfiro no aluno, no espaço dele ali em sala de aula porque isso é função do professor e não minha [...] (TILS 11).

Percebe-se uma fala mais técnica, de distanciamento por parte deste TILS, porém concomitantemente ele afirma que a atuação no ambiente educacional é diferenciada, necessitando de uma competência específica, a competência referencial, também citada pelo TILS 10. Entende-se competência referencial como a capacidade de se familiarizar com determinado assunto (AUBERT, 1994). 
[...] um conhecimento prévio eu acho interessante sim porque isso facilita né, o próprio processo de tradução e interpretação né, pra você conhecer um pouquinho do que você está trabalhando porque se você não tiver um acesso à mensagem até anterior, dependendo do tipo de discurso que vai ser traduzido, você se perde né, não basta só conhecer a língua de sinais, assim, você tem que ter outro conhecimento, que a gente chama no caso de competência referencial, você tá né, com um embasamento de conhecimento naquela área que você vai atuar.

[...] o IE ele tem que ter alguns conhecimentos prévios né, do campo que ele está atuando. Eu acredito que quando o IE tem formação na área, é um ganho muito grande, porque ele já vai ter estratégias especificas para atuar nesse campo, que vão facilitar. Não dá pro IE atuar da mesma forma que ele atua numa palestra, é um outro tipo de interpretação, ele tem que acompanhar o ritmo do professor, ele tem uma outra relação, aí ele já olha pros alunos, porque, se ele perceber que o aluno tá entendendo, o aluno levantar a mão, então ele tem que ter uma relação mais próxima com os alunos, o IE, não que ele vai interferir no trabalho do professor, mas na palestra a gente fixa o olhar num ponto e não tem essa relação e essa troca com o público surdo, mas na sala de aula, não, quando a gente tá interpretando e vê que o aluno não tá entendendo, a gente às vezes sinaliza pro professor, ou o próprio aluno tem a necessidade de levantar o dedo e a gente que tem que tá atento, então uma, a postura é outra, a gente tem essa prévia de acordar que é necessário que se posicionar ao lado do professor né, tem uma outra dinâmica de movimentação na sala de aula, de troca de olhar com o aluno, com o professor, então a atuação do IE é diferenciada e não é a mesma dos intérpretes que atuam em outros âmbitos né, em outras áreas. (TILS 11).

O terceiro TILS com esse perfil, todavia, possui uma visão diferenciada com relação ao papel do IE. Para ele, a função do intérprete está ligada somente a técnica tradutória.

Reponsabilidade?! De transmitir, só de transmitir o conhecimento! Na verdade, não o conhecimento, de transmitir a informação que eu estou recebendo, de forma clara, para esse surdo. Independente desse [...] se o conhecimento dele é vasto ou não. (TILS 9).

Um dado importante nessa análise é que este TILS vivenciou anteriormente uma situação interpretativa peculiar, onde atuava não como tradutor intérprete e sim como um "cuidador" ou tutor, segundo ele.

[...] antes eu via o papel do IE como um tutor, um responsável para educar, para resolver problema de surdo dentro do ambiente escolar e fora do ambiente escolar. Se o aluno chegava com piolho, se o aluno chegava com problema porque a mãe bateu, se o aluno brigou com a namorada, então todos os problemas sociais era o intérprete que tinha que resolver. E hoje eu vejo que o IE com, com todas essas formações e com a... a possibilidade, a vasta possibilidade de conhecimento de mundo que os surdos hoje estão inseridos, eu acho que hoje eu me 
considero que o IE, sim, é um mediador entre o professor e esse sujeito surdo sinalizante. (TILS 9).

\section{Discussão/ conclusão}

Após a análise dos perfis de TILS, observamos que pensar a formação desse profissional é uma discussão demasiadamente relevante não apenas para o seu campo formativo, mas para o melhor desenvolvimento educacional dos alunos surdos incluídos. Posto isto, colocamos nossas reflexões sobre os dados aqui apresentados, com o objetivo do aprimoramento da formação e atuação do intérprete educacional.

Kelman (2005) traz informações peculiares ao processo de atuação desse profissional intérprete em escolas públicas de ensino fundamental pesquisadas na cidade de Brasília, onde este assume um papel intrinsecamente diferenciado do que vemos na maioria dos espaços educativos. Os professores-intérpretes, assim denominados, são na realidade originalmente professores que possuem conhecimento em língua de sinais, podendo adotar a função de intérprete, corroborando com o fenômeno da codocência ${ }^{4}$.

Nos recortes supra analisados vemos, entretanto, emergir questionamentos e posicionamentos que contrariam esta realidade vivenciada em Brasília à época em que a pesquisa foi realizada. Todavia é perceptível que para atuar no ambiente educacional, os TILS necessitem de uma formação específica que abranja conhecimentos que os preparem para a realidade peculiar de sala de aula. Entendemos que este conflito e dúvida em relação às funções do IE não são apenas no Brasil. Conforme mencionado no texto, pesquisadores americanos também perceberam a presença desse conflito (WOLBERS et al., 2012) ao mencionarem a dupla possibilidade de interpretação: a paralela e a divergente.

Os intérpretes educacionais brasileiros carecem da percepção que a interpretação divergente, conforme definida por Wolbers et al. (2012), contribui para ampliar a compreensão e o conhecimento dos alunos surdos, devendo ser amplamente praticada.

Percebeu-se também que o quesito formação de IE inexiste como critério de seleção para atuarem em escolas, embora haja a certificação do Prolibras por parte de quase todos os entrevistados. Sabe-se, no entanto que a certificação não garante qualidade na interpretação, muito menos sob a ótica de atuação pedagógica. Em nosso entender, a formação do IE vai além do puro e simples ato interpretativo. O IE deve

\footnotetext{
4 "Codocência diz respeito a um trabalho compartilhado, de planejamento mútuo, integrado" (KELMAN, 2008, p.73).
} 
participar não apenas na construção do significado pelo aluno, mas no planejamento educacional, indicando quais os melhores recursos didáticos que venham a facilitar a formação de conceitos pelos alunos surdos. Vale ressaltar que o Prolibras não é uma formação, e sim uma certificação de proficiência da Língua de Sinais, criado como medida paliativa à crescente demanda de tais profissionais. Em nosso entender, inclusive, ele deveria ser um exame periódico, pois o grau de proficiência pode ser alterado, em função se o sujeito continua atuando ou não como intérprete. A certificação deveria ter prazo de validade, tendo que ser refeita após alguns anos.

Comparando algumas falas e posturas dentro dos perfis analisados nota-se que a percepção do papel do IE é algo que está em constante divergência de opiniões: alguns IEs não se sentem parte do processo de aprendizagem dos alunos surdos, ou seja, excluem totalmente sua função educacional. Percebem-se apenas como tradutor, eximindo-se de sua função como mediadores.

Enquanto alguns se veem dessa forma, outros se percebem para além dessa função, atuando como professor "bilíngue" e não como o intérprete mediador daquele aluno, tomando para si a responsabilidade docente. É importante destacar a tendência trazida por alguns dos entrevistados de que o professor regente delega ao intérprete o papel de ensino ao aluno surdo, negando os princípios fundamentais da inclusão. A invisibilidade do aluno surdo em classes inclusivas já havia sido destacada anteriormente (KELMAN; BUZAR, 2012) e aparece aqui também na medida em que uma professora, no meio do ano, achava que seu aluno tinha déficit de atenção e não surdez (fala de TILS 8). Cabe, portanto, ao intérprete, promover uma maior interação entre o professor regente e o aluno surdo, estimulando que o aluno surdo direcione suas perguntas ao professor, de forma a promover o diálogo entre ambos. Nesse momento, o IE deverá restringir-se à interpretação/tradução desse diálogo. Assim, além de assumir o ofício de interpretação/tradução, cabe a ele também a função de aproximação entre professor regente e os alunos surdos incluídos,

O papel de intérprete mediador deve ser abordado como alguém que vai transmitir conteúdos e gerar significações, garantindo não apenas a tradução daquele conteúdo, mas se a informação está sendo passada de maneira correta e se o conceito está sendo compreendido pelo aluno.

Segundo Lacerda (2005) o intérprete que desempenha somente a função de tradutor / intérprete em sala de aula não alcança resultado satisfatório na aprendizagem dos alunos surdos. A autora destaca ainda a necessidade de o intérprete atuar também 
como educador a fim de que o conteúdo explicado se torne mais acessível ao aluno surdo.

Isto posto, as hipóteses estabelecidas ao início deste ensaio se constituíram verídicas, uma vez que foi constatado que uma formação mais específica que englobe ambas as áreas do conhecimento (docência e tradutória) é o procedimento mais adequado para o processo formativo dos IEs. Esta afirmação pode ser endossada com discursos dos entrevistados independentemente de seu perfil.

A mediação predominantemente citada pelos TILS, em seu ato interpretativo, dá-se em um nível intermediário, isto é, o IE media o processo educacional sobre um viés integrador e concomitantemente pedagógico, sem assumir o papel efetivo de docente em sala de aula. "O intérprete educacional, em diversos momentos, exerce a função de educador, promovendo atividades mediadoras que auxiliam na construção de conceitos científicos pelo aluno surdo." (KELMAN; TUXI, 2010, p.99). Interpretar em salas de aula é mais do que ter competência em língua de sinais. Além de interpretar rápida e corretamente, o IE precisa facilitar que os alunos surdos possam alcançar os objetivos educacionais propostos pelo professor para todos os alunos da classe inclusiva.

Afirma-se, portanto, a necessidade de se continuar trazendo para o campo de discussão os conteúdos e as competências a serem delimitados para o processo de formação do profissional intérprete educacional, aproximando as narrativas que expressam a experiência desses profissionais com as reflexões decorrentes de pesquisas na área da educação de estudantes surdos. 


\section{EDUCATIONAL INTERPRETER: FORMATION AND ROLES IN CLASSROOMS}

ABSTRACT: It is fundamental that the educational interpreter participates in deaf students' inclusion. This paper approaches the formation and different roles that the interpreters occupy in inclusive educational settings. Is it sufficient to know Sign Language? Does it guarantee success while working? Signing is not enough; it is necessary to act as a mediator between regular teacher and deaf students, to promote comprehension. This paper investigates the reality of these interpreters through semistructured interviews with eleven professionals that work in inclusive educational spaces. We wanted to know about their professional formation, how long they have been conducting this function and what are the roles they play inside the classroom and in other spaces at school. Results show, among others, that there is still a lack of coplanning, teacher and interpreter and lack of previous access to information that will be dealt in classroom. Results also show that when the educational interpreter acts pedagogically action, deaf children learn more.

KEY WORDS: Interpreter formation. Inclusive education. Sign language.

\section{REFERENCIAS}

ALBRES, N. de A. A formação de intérpretes de libras para um serviço da educação especial. o que os currículos de cursos de especialização em libras têm a nos revelar? In: ENCONTRO DA ASSOCIAÇÃO BRASILEIRA DE PESQUISADORES EM EDUCAÇÃO ESPECIAL, 7., 2011, Londrina. Anais... Londrina: [s.n.], 2011. p.21512162. Disponível em:

<http://www.uel.br/eventos/congressomultidisciplinar/pages/arquivos/anais/2011/FOR MACAO/201-2011.pdf>. Acesso em: 23 set. 2015.

ALBRES, N. de A.; SANTIAGO, V. A. A. Atuação do intérprete educacional: reflexão e discussão sobre as duas modalidades de interpretação: simultânea e consecutiva.

Revista Espaço, Rio de Janeiro, n.38, p. 50-59, jul/dez. 2012.

AUBERT, F. H. As (in) fidelidades da tradução: servidões e autonomia do tradutor. Campinas: Ed. da Unicamp, 1994.

BRASIL. Lei $\mathrm{n}^{\circ}$ 12.319, de 1 de setembro de 2010. Regulamenta a profissão de Tradutor e Intérprete da Língua Brasileira de Sinais - LIBRAS. Diário Oficial [da] União, Brasília, 2 set. 2010. Disponível em:

<http://www.planalto.gov.br/ccivil_03/_Ato2007-2010/2010/Lei/L12319.htm>. Acesso em: 23 set. 2015.

. Decreto $\mathrm{n}^{\circ}$ 5.626, de 22 de dezembro de 2005. Regulamenta a Lei no 10.436, de 24 de abril de 2002, que dispõe sobre a Língua Brasileira de Sinais - Libras, e o art. 18 da Lei no 10.098, de 19 de dezembro de 2000. Diário Oficial [da] União, Brasília, 23 dez. 2005. Disponível em: <http://www.planalto.gov.br/ccivil_03/_ato20042006/2005/decreto/d5626.htm>. Acesso em: 23 set. 2015. 
Lei $\mathrm{n}^{\circ} 10.436$, de 24 de abril de 2002. Dispõe sobre a Língua Brasileira de Sinais - Libras e dá outras providências. Diário Oficial [da] União, Brasília, 25 abr. 2002. Disponível em: <http://www.planalto.gov.br/ccivil_03/leis/2002/L10436.htm>. Acesso em: 23 set. 2015.

BUENO, J. G. S. Crianças com necessidades educativas especiais, política educacional e a formação de professores: generalistas ou especialistas? Revista Brasileira de Educação Especial, Piracicaba, v.3, n.5, p.7-25, 1999.

CÓRDOVA, B. C. Concepções de intérpretes de língua de sinais acerca de sua atuação em contextos educacionais. 2009. 78f. Dissertação (Mestrado em Educação)Universidade de Brasília, Faculdade de Educação, Brasília, 2009.

DORZIAT, A.; ARAÚJO, J. R. O intérprete de língua de sinais no contexto da educação inclusiva: o pronunciado e o executado. Revista Brasileira de Educação Especial, Marília, v.18, n.3, p.391-410, jul/set. 2012.

FREITAS, M. T. A. A abordagem sócio-histórica como orientadora de pesquisa qualitativa. Cadernos de Pesquisa, São Paulo, n. 116, p.21-39, jul. 2002.

KELMAN, C. A. O intérprete educacional: quem é? O que faz? In: ALMEIDA, M. A.; MENDES, E.G.; HAYASHI, M. C. P. I. (Org.). Temas em educação especial: deficiências sensoriais e deficiência mental. Araraquara: Junqueira \& Marin, 2008. p.71-79.

Os diferentes papéis do professor intérprete. Revista Espaço, Rio de Janeiro, v.24, p.25-30, 2005.

KELMAN, C. A.; BUZAR, E. A. A (in)visibilidade do aluno surdo em classes inclusivas: discussões e reflexões. Revista Espaço, Rio de Janeiro, n.37, p.04-13, jan./jun. 2012.

KELMAN, C. A.; TUXI, P. Intérprete educacional ou professor? a atuação profissional do intérprete da língua de sinais no ensino de ciências. In: SALLES, P. S. B. A.; GAUCHE, R. (Org.). Educação científica, inclusão social e acessibilidade. Goiânia: Cânone, 2010. p.79-104.

KOTAKI, C. S.; LACERDA, C. B. de F. O intérprete de LIBRAS no contexto da escola incusiva. In: LACERDA, C. B. de F.; SANTOS, L. F. dos. Tenho um aluno surdo, e agora? São Carlos: EDUFSCAR, 2013. p.201-218.

LACERDA, C. B. F. Intérprete de libras: em atuação na educação infantil e no ensino fundamental. 5.ed. Porto Alegre: Mediação, 2013.

Tradutores e intérpretes de língua brasileira de sinais: formação e atuação nos espaços educacionais inclusivos. Cadernos de Educação, Pelotas, v.36, p.133-153, maio/ago. 2010.

A escola inclusiva para surdos: a situação singular do intérprete de língua de sinais. Contrapontos, Itajaí, v.5, n.3, p.353-367, 2005. 
LACERDA, C. B. F.; LODI, A. C. B. A inclusão escolar bilíngüe de alunos surdos no ensino infantil e fundamental: princípios, breve histórico e perspectivas. In: LODI, A. C. B. L.; LACERDA, C. B. F. (Org.). Uma escola duas línguas: letramento em língua portuguesa e língua de sinais nas etapas iniciais de escolarização. Porto Alegre: Ed. Mediação, 2009. v.1. p.11-32.

MADUREIRA, A. F.; BRANCO, A. M. U. A pesquisa qualitativa em psicologia do desenvolvimento: questões epistemológicas e implicações metodológicas. Temas em Psicologia, Ribeirão Preto (SP), v.9, n.1, p.63-75, 2001.

MANZINI, E. J. Considerações sobre a elaboração de roteiro para uma entrevista semiestruturada. In: MARQUEZINE, M. C.; ALMEIDA, M. A.; OMOTE, S. (Org.).

Colóquios sobre pesquisa em educação especial. Londrina: EDUEL, 2003. p.11-25.

QUADROS, R. M. O tradutor e intérprete de língua brasileira de sinais e língua portuguesa. 2.ed. Brasília: MEC, 2004. v. 1.

SALES, A. de C. M. Diálogos com tradutores-intérpretes de língua de sinais que atuam no ensino fundamental. 2014. 219f. Tese (Doutorado em Educação Especial)Universidade Federal de São Carlos, Centro de Ciências Humanas, São Carlos, 2014.

SILVA, R. C. J.; KELMAN, C. A.; SALLES, H. M. M. L. Formação de professores na educação de surdos. In: SALLES, P. S. B. A.; GAUCHE, R. (Org.). Educação científica, inclusão social e acessibilidade. Goiania: Cânone, 2010. p.57-78.

WOLBERS, K. A. et al. Parallel and divergent interpreting in an elementary school classroom. American Annals of the Deaf, [S.1.], v.157, n.1, p.48-65, 2012. 